\title{
Strain-Specific Differences in House Dust Mite (Dermatophagoides farinae)-Induced Mouse Models of Allergic Rhinitis
}

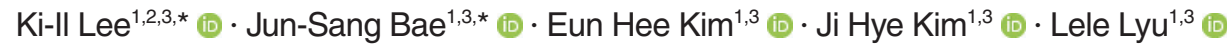 \\ Young-Jun Chung ${ }^{1}$ (iD $\cdot$ Ji-Hun $\mathrm{Mo}^{1,3}$ (iD \\ ${ }^{1}$ Department of Otorhinolaryngology-Head and Neck Surgery, Dankook University College of Medicine, Cheonan; \\ ${ }^{2}$ Department of Otorhinolaryngology-Head and Neck Surgery, Konyang University College of Medicine, Daejeon; \\ ${ }^{3}$ Beckman Laser Institute Korea, Dankook University College of Medicine, Cheonan, Korea
}

Objectives. Limited information is available regarding strain-related differences in mouse models of allergic rhinitis induced by Dermatophagoides farinae (Der f1). In this study, we compared differences between two mouse strains and determined the optimal dose of Der f1 for allergic rhinitis mouse models.

Methods. Forty-eight mice were assigned to the following six groups ( $\mathrm{n}=8$ per group): group A (control, BALB/c), group $\mathrm{B}$ (Der f1-sensitized BALB/c, $25 \mu \mathrm{g}$ ), group C (Der f1-sensitized BALB/c, $100 \mu \mathrm{g}$ ), group D (control, C57BL/6), group E (Der f1-sensitized C57BL/6, $25 \mu \mathrm{g}$ ), and group F (Der f1-sensitized C57BL/6, $100 \mu \mathrm{g}$ ). Allergic inflammation was induced with Der f1 and alum sensitization, followed by an intranasal challenge with Der f1. Rubbing and sneezing scores, eosinophil and neutrophil infiltration, and immunoglobulin, cytokine, and chemokine levels in the nasal mucosa and from splenocyte cultures were assessed.

Results. Rubbing and sneezing scores were higher in groups B, C, E, and F than in groups A and D, with a similar pattern in both strains (i.e., group B vs. E and group C vs. F). Serum immunoglobulin levels were significantly elevated compared to the control in groups $\mathrm{B}$ and $\mathrm{C}$, but not in groups $\mathrm{E}$ and $\mathrm{F}$. Eosinophil and neutrophil infiltration increased (all $P<0.05)$ after the Der f1 challenge (groups B, C, E, and F) compared to the control (groups A and D) in both the BALB/c and C57BL/6 strains, without any significant difference between the two strains (group A vs. D, group B vs. E, and group $\mathrm{C}$ vs. F) $(P>0.05)$. BALB/c mice (group B) showed a greater elevation of splenic interleukin (IL)-4 $(P<0.01)$, IL-5 $(P<0.01)$, and IL-6 levels $(P<0.05)$ and nasal IL-4 mRNA levels $(P<0.001)$ than the C57BL/6 mice (group E). Interestingly, mice treated with $100 \mu \mathrm{g}$ Der f1 showed a weaker allergic response than those treated with $25 \mu \mathrm{g}$.

Conclusion. We found $25 \mu \mathrm{g}$ to be a more appropriate dose for Der $\mathrm{f} 1$ sensitization. BALB/c mice are more biased toward a Th2 response and are a more suitable model for allergic rhinitis than C57BL/6 mice. This study provides information on the appropriate choice of a mouse model for allergic rhinitis.

Keywords. Animal Model; Allergic Rhinitis; Mice; Dermatophagoides Farinae; Immunoglobulin

\footnotetext{
- Received November 12, 2019

Revised February 9, 2020

Accepted February 10, 2020

- Corresponding author: Ji-Hun Mo

Department of Otorhinolaryngology-Head and Neck Surgery, Dankook

University College of Medicine, 119 Dandae-ro, Dongnam-gu,

Cheonan 31116, Korea

Tel: +82-41-550-3933, Fax: +82-41-556-1090

E-mail: jihunmo@gmail.com

*The first two authors contributed equally to this study.
}

\section{INTRODUCTION}

Allergic rhinitis markedly affects patients' quality of life, and it is a major reason for outpatient visits to otolaryngology clinics [1-5]. Allergic rhinitis is generally thought to be mediated by Th2, with interleukin (IL)-4, IL-5, and IL-13 also contributing to its pathogenesis [6]. Clinically, establishing satisfactory animal models is critical for the development of effective treatments for

Copyright (C) 2020 by Korean Society of Otorhinolaryngology-Head and Neck Surgery.

This is an open-access article distributed under the terms of the Creative Commons Attribution Non-Commercial License (https://creativecommons.org/licenses/by-nc/4.0)

which permits unrestricted non-commercial use, distribution, and reproduction in any medium, provided the original work is properly cited. 
allergic rhinitis. Studies have demonstrated that several mouse strains are Th2-biased (BALB/c, BP2, and $\mathrm{A} / \mathrm{J})$, while others are Th1-biased (C57BL/6, DBA/2, AKR, and CBA) [7]. BALB/c mice are generally preferred for studies on allergic immune responses, as this strain has been found to provide more robust allergic rhinitis responses than the C57BL/6 strain in studies using the Schistosoma mansoni egg antigen as an allergen [8]. In contrast, other studies have shown that C57BL/6 mice develop exaggerated Th1-biased responses and relatively strong inflammation compared to BALB/c mice [9]. Most studies that have used these murine models to study allergic responses (such as those involved in asthma) have mainly focused on the lower airway, whereas studies focusing on allergic inflammation in the upper airway are lacking.

Few studies have specifically characterized differences between mouse strains in allergic immune responses in the upper airway. Additionally, most previous studies have used a model of ovalbumin (OVA) sensitization to induce allergic rhinitis in mice [10-13]. This model is well-established and popular for allergic airway inflammation due to the ease with which it can be used to assess systemic allergic reactions. However, OVA is not an antigen that patients are naturally exposed to, which limits the model's clinical relevance. The house dust mite (HDM) is the most common cause of allergic diseases, and Dermatophagoides farinae (Der f) and Dermatophagoides pteronyssinus (Der p) are known contributors to this disease [14,15]. Mouse models of allergic rhinitis induced by HDM antigens have recently been established. Der f1, Der p1, Der f2, and Der p2 have been identified and purified from crude mite extracts, and are now wellestablished as clinically important allergens [16]. However, insufficient data are available regarding HDM allergens and discrepancies in sensitivity between mouse strains. Accordingly, in the current study, we aimed to compare susceptibility to allergic rhinitis in BALB/c and C57BL/6 mouse strains using the Der f1 allergen.

\section{H I G G L L I G}

- Our study found $25 \mu \mathrm{g}$ of Dermatophagoides farinae (Der f1) to be the optimal dose for general sensitization and experimental allergic rhinitis.

- BALB/c mice are more biased towards a Th2 response than C57BL/6 mice and serve as a more suitable animal model of experimental allergic rhinitis.

- This is the first study to compare the susceptibility of mouse strains to an allergic rhinitis model using Der f1, and differences were found in the severity of airway tissue inflammation and cytokine responses between strains.

- This study could be helpful in selecting the appropriate mouse strain for allergic rhinitis mouse models.

\section{MATERIALS AND METHODS}

The Committee on the Use and Care of Animals of the institution approved the animal experiments and the study complied with the governmental and international guidelines on animal experimentation (No. DK-13-017).

\section{Animals and grouping}

Forty-eight mice were used and experiments were repeated twice for nasal mucosal histology $(\mathrm{n}=24)$ and nasal mRNA analysis $(n=24)$. Female BALB/c and C57BL/6 mice (4 weeks of age, 20-25 g; Narabio Co., Seoul, Korea) were divided into six groups $(\mathrm{n}=4$ for each) in each experiment as follows: BALB/c control group (group A), 25- $\mu$ g Der f1-exposed BALB/c group (group B), 100- $\mu g$ Der f1-exposed BALB/c group (group C), C57BL/6 control group (group D), $25-\mu \mathrm{g}$ Der f1-exposed C57BL/6 group (group E), and 100- $\mu g$ Der f1-exposed C57BL/6 group (group F).

\section{Sensitization protocol and allergen exposure}

The allergic rhinitis model was induced by exposing the mice to Der f1-alum on days 0,7 , and 14 via intraperitoneal injection (Der f1-alum sensitization). Mice were injected intraperitoneally on days 0,7 , and 14 with $25 \mu$ of Der f1 (groups B and E) or $100 \mu \mathrm{g}$ of Der $\mathrm{f1}$ (groups $\mathrm{C}$ and $\mathrm{F}$ ) in $1 \mathrm{mg}$ of aluminum hydroxide gel. The control mice (groups A and D) were sensitized intraperitoneally with phosphate buffered saline (PBS; PBS sensitization). The experimental mice (groups B, C, E, and F) were exposed intranasally to $20 \mu \mathrm{g}$ Der f1 diluted in $40 \mu \mathrm{L}$ of PBS and control mice (groups A and D) were treated similarly with PBS daily for 7 consecutive days from day 21 to 27 (intranasal Der

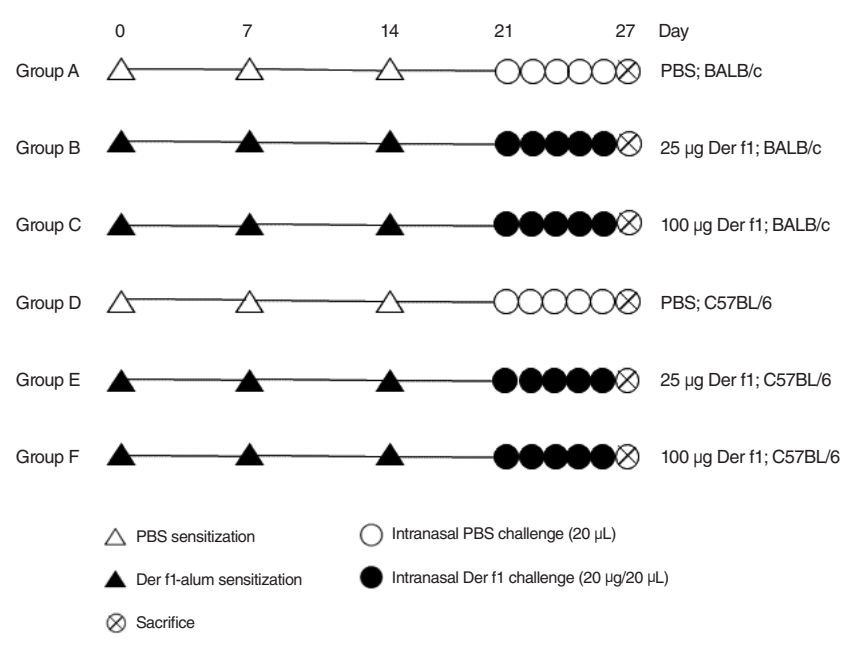

Fig. 1. Experimental protocol. Group $A$, control group of BALB/C mice; Group B, BALB/c mice exposed to $25 \mu \mathrm{g}$ of Dermatophagoides farinae (Der f1); Group C, BALB/c mice exposed to $100 \mu \mathrm{g}$ of Der f1; Group D, control group of C57BL/6 mice; Group E, C57BL/6 mice exposed to $25 \mu \mathrm{g}$ of Der f1; Group F, C57BL/6 mice exposed to $100 \mu \mathrm{g}$ of Der f1; PBS, phosphate buffered saline. 
f1 and PBS challenge). Mice were sacrificed on day 27 (Fig. 1). Der f1 was distributed from Arthropods of Medical Importance Resource Bank (Seoul, Korea).

\section{Evaluation of clinical signs and tissue preparation}

An observer who was blinded to this experiment counted the frequency of rubbing and sneezing events during a 20-minute period after the last allergen exposure. Mice were then euthanized, and heads were removed en bloc, and fixed in $4 \%$ paraformaldehyde for histologic examination. RNA was obtained from the nasal mucosa for the assessment of cytokine gene expression by real-time polymerase chain reaction (PCR), as later described.

Measurements of total lgE, Der f1-specific lgE, Der f1-specific IgG1, and Der f1-specific lgG2a in serum

Sera were collected with a syringe from the retro-orbital vessels of mice to measure serum immunoglobulin levels (total serum immunoglobulin [Ig] E, Der f1-specific IgE, Der f1-specific IgG1, and Der f1-specific IgG2a). Serum levels of total and Der f1specific immunoglobulins were calculated using a Mouse IgE enzyme-linked immunosorbent assay (ELISA) set (555248; BD Pharmingen, San Diego, CA, USA). Serum samples collected from mice at the time of killing were serially diluted and then added to 96-well plates coated with purified anti-mouse IgE $\mathrm{mAb}$ (clone R35-72, BD Pharmingen). A purified mouse IgG1 isotype (A85-1, BD Pharmingen) was used as a standard for total IgE, and 3\% bovine serum albumin was used to block nonspecific antigen-antibody reactions. A purified mouse IgG2a isotype (R19-15; SouthernBiotech, Birmingham, AL, USA) was subtracted to the plate in order to measure the levels of total IgE. Biotin-labeled Der f1 was added to detect Der f1-specific IgE, Der f1-specific IgG1, and Der f1-specific IgG2a, followed by Streptavidin-HRP (890803; R\&D Systems, Minneapolis, MN, USA). The reactions were developed using the 1-Step Ultra TMB-ELISA (34028; Thermo Scientific, Waltham, MA, USA) and were terminated by the addition of $1 \mathrm{M} \mathrm{HCl}$. The optical density (OD) was documented by using a luminometer (iEMS Reader; Labsystems, Helsinki, Finland) set at $450 \mathrm{~nm}$. The endpoint titers of Der f1-specific IgE, Der f1-specific IgG1, and Der f1-specific IgG2a were manifested as the reciprocal $\log 2$ value of the last dilution from a sample that resulted in an OD value 0.1 units greater than the background.

\section{Histopathological analysis}

Nasal tissues were decalcified, embedded in paraffin, and sectioned coronally (4- $\mu \mathrm{m}$ thickness) at a distance approximately $5 \mathrm{~mm}$ from the nasal vestibule for the evaluation of nasal histology. Sirius Red staining was then conducted to compare eosinophil infiltration between the groups. Five areas from the mice mucosal sections were chosen randomly for evaluation. The number of eosinophils were counted under high-power fields
(HPFs; $10 \times 40$ ) by an examiner who was blinded to the groups. Three continuous slides were reviewed to exclude processing errors.

\section{Immunohistochemistry}

For the evaluation of neutrophils, interleukin (IL)-25, and IL-33, nasal sections were immunostained using avidin-biotinylatedhorseradish peroxidase-complex kits (ABC; PK6100, Vector Laboratories, Burlingame, CA, USA). Nasal sections were rehydrated with ethanol after deparaffinization in xylene, blocked with $5 \% \mathrm{BSA}$, and treated with each primary polyclonal antibody for neutrophils (1:100, ab2557; Abcam, Cambridge, UK), IL-25 (1:100, \#06-1080; Merck Millipore, Temecula, CA, USA), and IL-33 (1:100,AF3626; R\&D Systems) at $4^{\circ} \mathrm{C}$ overnight in a humidified chamber after washing with PBS. The sections were incubated for 90 minutes at room temperature with a secondary antibody (biotin-conjugated goat anti-rabbit immunoglobulin G (1:200, BA-1000; Vector Laboratories) and biotin-conjugated goat anti-rat immunoglobulin G (1:200, BA-9400; Vector Laboratories). Subsequently, the samples were rinsed with PBS, and incubated with $\mathrm{ABC}$ for 60 minutes at room temperature. After another wash with PBS, samples were developed with a peroxidase substrate kit (DAB; Sk-4100, Vector Laboratories) containing $0.003 \%$ hydrogen peroxide. Lastly, the sections were counterstained with hematoxylin (Sigma-Aldrich, St. Louis, MO, USA). Each section was examined based on HPFs $(10 \times 40)$ by an independent researcher blinded to the experimental parameters. Darkbrown staining was considered a positive signal for the nasal septal mucosa sections. The quantification of immunohistochemical staining in each section was measured using Image J program (U.S. National Institutes of Health, Bethesda, MD, USA).

\section{Real-time reverse-transcription PCR in the nasal mucosa}

Total RNA was extracted from the cells using TriZol Reagent (Invitrogen, Carlsbad, CA, USA). Next, cDNA was synthesized using Superscript Reverse Transcriptase (Invitrogen) and oligo (dT) primers (Fermentas, Waltham, MA, USA). Real-time PCR was performed using theTaqman method with an ABI7500 (Applied Biosystems, Piscataway, NJ, USA). For the analysis of IL-4 (Mm00445258_g1), IL-17A (Mm00439618_m1), IL-10 (Mm00439616_m1), IL-5 (Mm00439646_m1), IL-6 (Mm00446190_ m1), interferon-gamma (IFN- $\gamma$; Mm99999071_m1), and glyceraldehyde 3-phosphate dehydrogenase (GAPDH; Mm03302249_g1 for mouse), Taqman Gene Expression Master Mix (4369016,Applied Biosystems) containing primers and probes was purchased from Applied Biosystems (Foster City, CA, USA). The cDNA was amplified using MicroAmp optical 96-well reaction plates (Applied Biosystems). The reaction was measured using a StepOnePlus Real-Time PCR System (one cycle of $50^{\circ} \mathrm{C}$ for 2 minutes followed by one cycle of $95^{\circ} \mathrm{C}$ for 10 minutes and 40 cycles of $95^{\circ} \mathrm{C}$ for 15 seconds, and $60^{\circ} \mathrm{C}$ for 1 minute as per manufacturer's protocol (Applied Biosystems). The average transcript levels 
of genes were normalized to GAPDH expression using the $2^{-\triangle \Delta C T}$ method. Likewise, cDNA was synthesized and analyzed for local chemokines including Eotaxin-1 (Mm00441238_m1 Ccl11), Eotaxin-2 (Mm00444701_m1 Ccl24), CXCL1 (Mm04207460_m1 Cxcl1), and CXCL2 (Mm00436450_m1 Cxcl2) by performing real-time PCR in the same manner.

Assessment of systemic cytokines (IL-4, IL-5, IL-6, IL-10, IL-17A, and IFN- $\gamma$ )

The spleens of mice were removed aseptically, and splenic mononuclear cells were plated in 24-well tissue culture plates at a concentration of $3 \times 10^{6}$ cells/mL using RPMI640 media (10-040CVR; Corning, Steuben County, NY, USA). After incubation in a $\mathrm{CO}_{2}$ incubator at 37 for 72 hours, the cells were stimulated with Der $\mathrm{f} 1$ for 72 hours, and cell culture supernatants were stored at $-70^{\circ} \mathrm{C}$ until cytokines were measured. Cytokines in culture supernatants were assayed using a sandwich ELISA kit (R\&D Systems), according to the manufacturer's instructions. The concentrations of IL-4 (DY-404), IL-5 (DY-405), IL-6 (DY-406), IL-10 (DY-407), IL-17 (DY-421), and IFN- $\gamma$ (DY-485) were determined based on interpolation from a standard curve after measuring the $\mathrm{OD}$ at $450 \mathrm{~nm}$ (all results are expressed as $\mu \mathrm{g} / \mathrm{mL}$ ).

\section{Statistical analysis}

Symptom scores, nasal tissue histopathology results, and immunoglobulin and systemic cytokine levels were presented as mean \pm standard error of the mean, and cross-group comparisons were performed using the Mann-Whitney $U$-test. Comparisons among groups were performed based on the Kreskas-Wallis test with Dunn's multiple comparisons test. The $P$-values less than 0.05 were considered statistically significant. The MannWhitney $U$ and Kruskal-Wallis tests were implemented using GraphPad InStat version 5.0 (GraphPad Software, San Diego, CA, USA).

\section{RESULTS}

\section{Mice exposed to a low dose $(25 \mu \mathrm{g})$ of Der $\mathrm{f} 1 \mathrm{had}$ higher rubbing and sneezing scores}

The symptom scores for groups A (20.8 \pm 18.4$)$, B (50.0 \pm 13.5$)$, C (35.5 \pm 19.7$), \mathrm{D}(22.0 \pm 10.4), \mathrm{E}(50.8 \pm 20.5)$, and F (36.8 \pm 6.1) were recorded (Fig. 2). The rubbing and sneezing scores of groups $\mathrm{B}$ and $\mathrm{E}$ were significantly higher than those of their respective control groups (A and $\mathrm{D}$; both $P<0.05$ ). However, no significant differences were observed between the BALB/c and C57BL/6 strains $(P=0.13)$.

\section{$\mathrm{BALB} / \mathrm{c}$ mice had higher serum immunoglobulin levels than C57BL/6 mice}

The total serum IgE levels were measured in groups A $(0.0 \pm$ $0.0 \mu \mathrm{g} / \mathrm{mL}), \mathrm{B}(17.2 \pm 4.6 \mu \mathrm{g} / \mathrm{mL}), \mathrm{C}(7.7 \pm 5.1 \mu \mathrm{g} / \mathrm{mL}), \mathrm{D}(1.5 \pm$

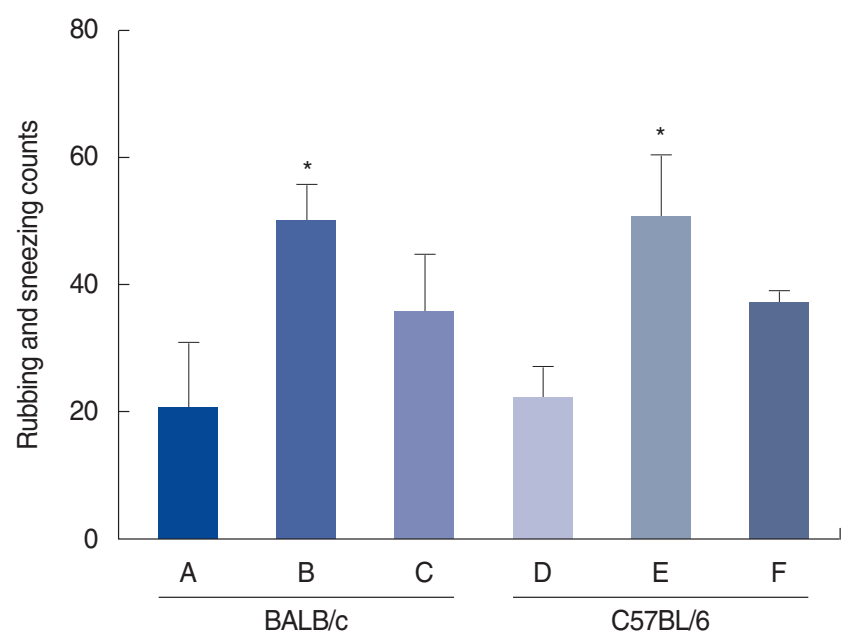

Fig. 2. Rubbing and sneezing counts. Control group of BALB/c mice (group A), BALB/c mice exposed to $25 \mu \mathrm{g}$ of Dermatophagoides farinae (Der $\mathrm{f1}$; group $\mathrm{B}$ ), BALB/c mice exposed to $100 \mu \mathrm{g}$ of Der $\mathrm{f1}$ (group C), control group of C57BL/6 mice (group D), C57BL/6 mice exposed to $25 \mu \mathrm{g}$ of Der f1 (group E), and C57BL/6 mice exposed to $100 \mu \mathrm{g}$ of Der $\mathrm{f} 1$ (group F). Bars represent standard error. Significantly different from control mice, ${ }^{*} P<0.05$.

$1.5 \mu \mathrm{g} / \mathrm{mL}), \mathrm{E}(2.1 \pm 2.1 \mu \mathrm{g} / \mathrm{mL})$, and F (5.2 $\pm 5.2 \mu \mathrm{g} / \mathrm{mL})$ (Fig. 3A). The total IgE level was significantly higher $(P<0.001)$ in BALB/c mice that were challenged with a low dose $(25 \mu \mathrm{g})$ of Der $\mathrm{f} 1$ (group B). Interestingly, the total IgE levels were lower in BALB/c mice that had been challenged with a higher dose $(100 \mu \mathrm{g})$ of Der f1 (group C). In C57BL/6 mice, the highest total IgE levels were observed in mice challenged with a higher dose of Der f1 (group F); however, no statistically significant differences were detected compared with group $\mathrm{D}(P=0.43)$. BALB/c mice showed a more robust total serum IgE response than C57BL/6 mice. Serum Der f1-specific IgE levels were measured by ELISA in groups A $(0.1 \pm$ 0.0 units), $\mathrm{B}$ ( $1.0 \pm 0.1$ units), C ( $0.3 \pm 0.1$ units), $\mathrm{D}$ ( $0.3 \pm 0.1$ units), $\mathrm{E}(0.1 \pm 0.1$ units), and $\mathrm{F}$ ( $0.3 \pm 0.0$ units), as shown in Fig. 3B. We similarly observed a significant elevation in Der f1-specific IgE levels in BALB/c mice that were challenged with a low dose of Der $\mathrm{f1}(P<0.001)$, but the response in C57BL/6 mice was not statistically significant $(P=0.08)$. Serum Der f1-specific IgG1 levels were also measured by ELISA in groups A ( $0.1 \pm 0.0$ units), $\mathrm{B}(1.0 \pm 0.1$ units), C (0.8 \pm 0.3 units), D (0.2 \pm 0.1 units), E (0.1 \pm 0.0 units), and $\mathrm{F}(0.2 \pm 0.1$ units $)$, as shown in Fig. 3C. BALB/c mice showed higher levels of Der f1-specific IgG1 than C57BL/6 mice, and the highest IgG1 level was found in BALB/c mice challenged with a low dose of Der f1 (group B, $P<0.001$ ). Serum Der f1-specific IgG2a levels were measured in groups A $(0.1 \pm$ 0.0 units), B (2.3 \pm 0.4 units), C (2.8 \pm 0.6 units), D (0.2 \pm 0.1 units), $\mathrm{E}(0.2 \pm 0.1$ units), and $\mathrm{F}(0.5 \pm 0.1$ units), as presented in Fig. 3D. BALB/c mice showed higher levels of Der f1-specific IgG2a than C57BL/6 mice. Although serum Der f1-specific IgG2a levels were elevated in BALB/c mice, no significant differences was observed between groups $\mathrm{B}$ and $\mathrm{C}(P=0.10)$. 

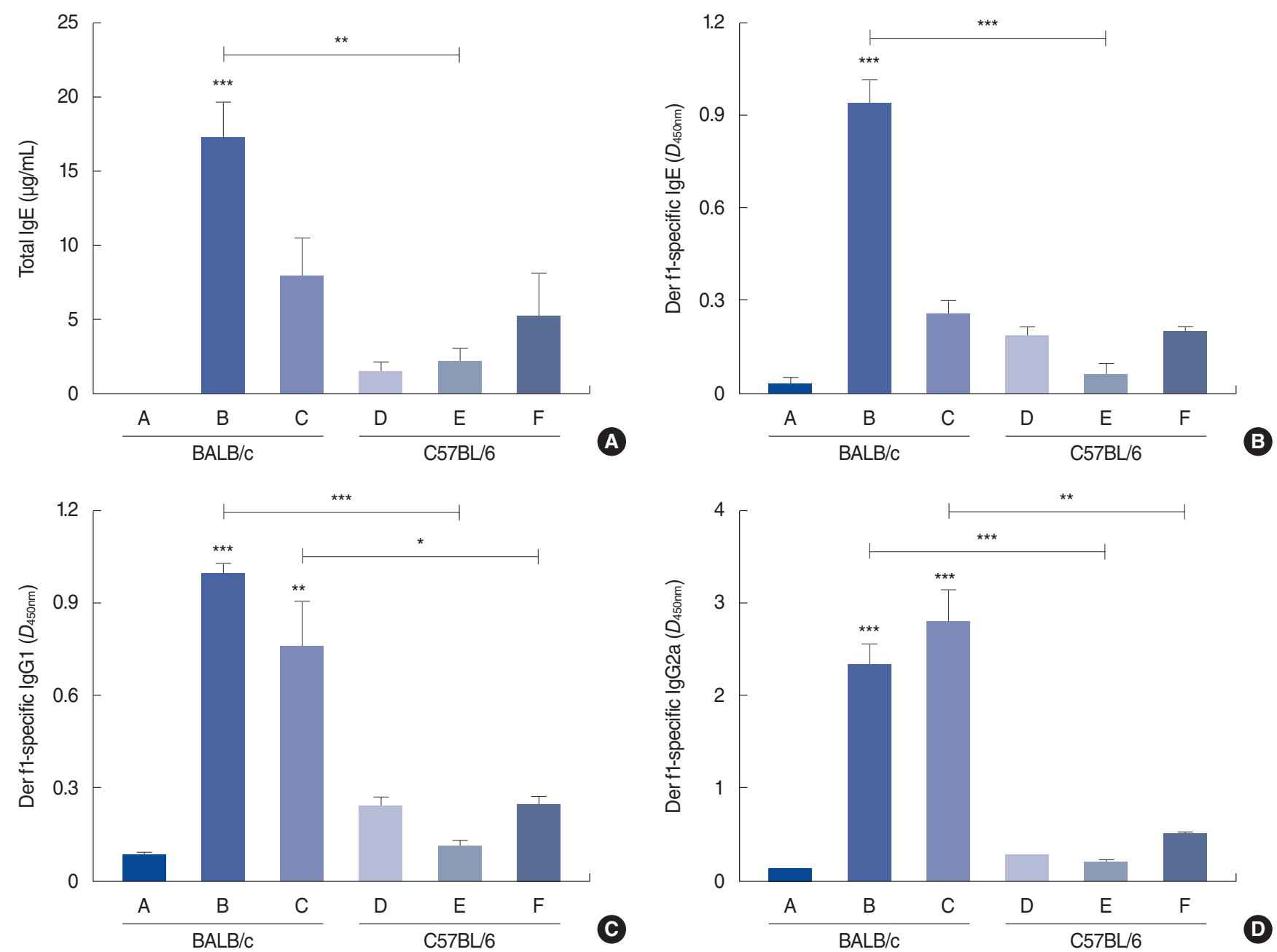

Fig. 3. Serum immunoglobulin (Ig) levels. (A) Total IgE levels from serum. (B) Der f1-specific IgE levels from serum. (C) Der f1-specific IgG1 levels from serum. (D) Der f1-specific IgG2a levels from serum. Control group of BALB/c mice (group A), BALB/c mice exposed to $25 \mu \mathrm{gg}$ of Dermatophagoides farinae (Der f1; group B), BALB/c mice group exposed to $100 \mu \mathrm{gg}$ of Der f1 (group C), control group of C57BL/6 mice (group D), C57BL/6 mice exposed to $25 \mu \mathrm{g}$ of Der f1 (group E), and C57BL/6 mice exposed to $100 \mu \mathrm{g}$ of Der f1 (group F). Bars represent standard error. Significantly different from control mice or significantly different between strains, ${ }^{\star} P<0.05,{ }^{\star \star} P<0.01,{ }^{* \star *} P<0.001$.

Mice exposed to a low dose of Der f1 had higher eosinophil and neutrophil infiltration in the nasal mucosa Eosinophil infiltration

The number of eosinophils per HPF was counted in groups A (43.8 \pm 18.0$),$ B $(250.4 \pm 86.4), C(80.3 \pm 61.2), D(6.3 \pm 4.8), \mathrm{E}$ (249.0 \pm 37.4$)$, and $F(157.0 \pm 57.3)$. A robust elevation in eosinophil infiltration was noted in both BALB/c and C57BL/6 mice treated with a low dose of Der f1 (groups B and E) compared to their respective control groups (groups $\mathrm{A}$ and $\mathrm{D}, P=0.002$ and $P<0.001$, respectively), as shown in Fig. 4A. Both mouse strains treated with a low dose of Der f1 also had higher eosinophil infiltration than their respective higher-dose groups (groups $\mathrm{C}$ and F, $P<0.05$ for both), as shown in Fig. 4B.

\section{Neutrophil infiltration}

The number of neutrophils per HPF was counted in groups A
(33.0 \pm 11.7$),$ B $(90.8 \pm 21.4), C$ ( $58.5 \pm 22.7), \mathrm{D}(28.3 \pm 8.5), \mathrm{E}$ (68.0 \pm 21.5$)$, and $F(56.0 \pm 19.1)$. Neutrophil infiltration was most prominent in group B. Expression of a neutrophil-specific marker was higher in groups $\mathrm{B}, \mathrm{E}$, and $\mathrm{F}$ than in their respective control groups in both strains (groups A and C, $P<0.01, P<0.05$, and $P<0.01$ ), as presented in Fig. 5. Neutrophil infiltration appeared to be higher in BALB/c mice than in C57BL/6 mice; however, there was no statistically significant difference between the two groups $(P>0.05)$.

Levels of innate cytokines (IL-25 and IL-33)

In recent years, the innate cytokines IL-25, IL-33, and thymic stromal lymphopoietin have been found to play an important role in allergic Th2 inflammation. The levels of innate cytokines were measured using immunohistochemistry. IL-25 expression was higher in groups B, E, and F than in their respective control 

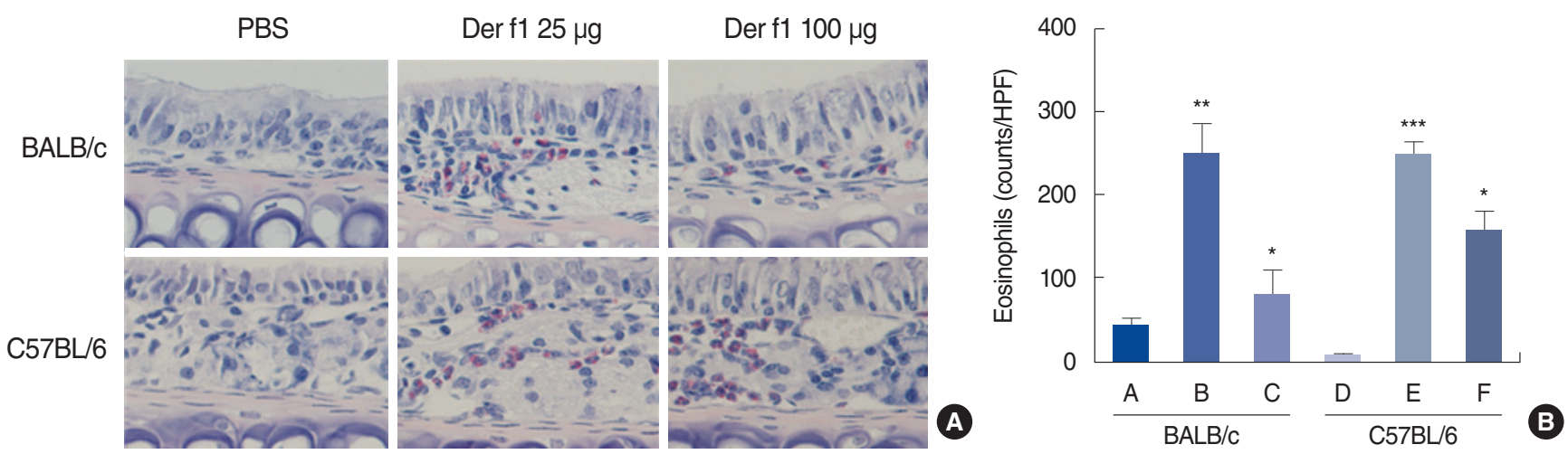

Fig. 4. Eosinophil infiltration in the nasal mucosa. (A) Representative microphotographs ( $\times 400)$, and (B) quantitative analyses of eosinophil infiltration in the nasal mucosa. The panels show Sirius Red staining $(\times 400)$. Control group of BALB/c mice (group A), BALB/c mice exposed to $25 \mu \mathrm{g}$ of Dermatophagoides farinae (Der f1; group B), BALB/c mice group exposed to $100 \mu \mathrm{g}$ of Der f1 (group C), control group of C57BL/6 mice (group D), C57BL/6 mice exposed to $25 \mu \mathrm{g}$ of Der f1 (group E), and C57BL/6 mice exposed to 100 gg of Der f1 (group F). PBS, phosphate buffered saline; HPF, high-power field. Bars represent standard error. Significantly different from control mice, ${ }^{\star} P<0.05$, ${ }^{\star \star} P<0.01$, ${ }^{\star \star \star} P<0.001$.
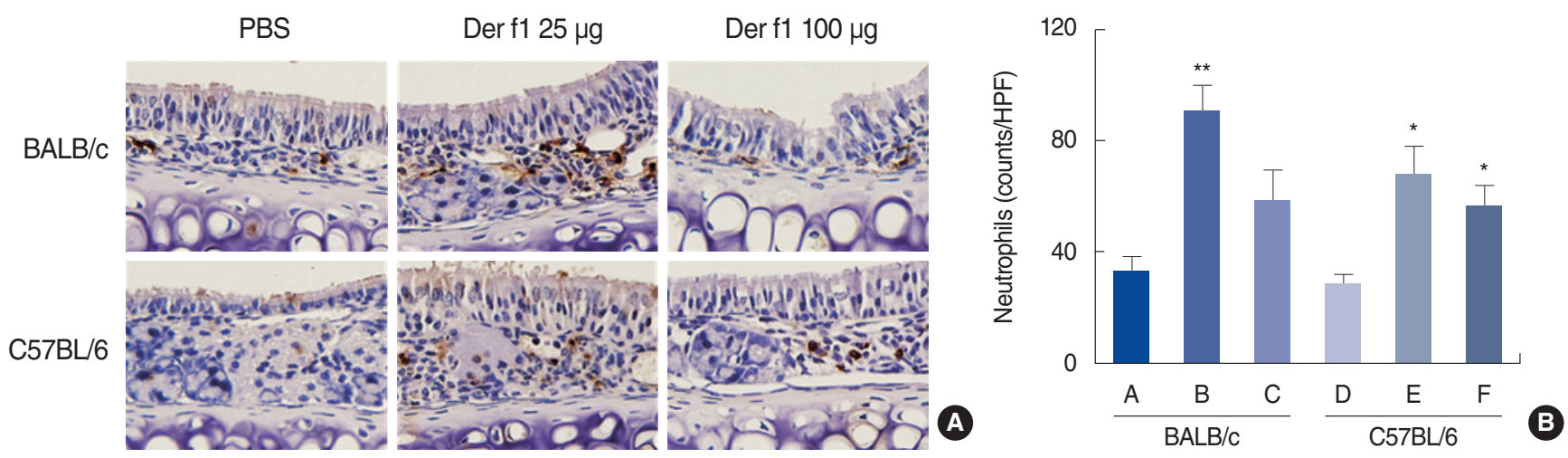

Fig. 5. Infiltration of neutrophils in the nasal mucosa. The panels show immunohistochemical findings for neutrophils $(\times 400)$. Control group of BALB/c mice (group A), BALB/c mice exposed to $25 \mu \mathrm{g}$ of Dermatophagoides farinae (Der f1; group B), BALB/c mice group exposed to 100 $\mu \mathrm{g}$ of Der f1 (group C), control group of C57BL/6 mice (group D), C57BL/6 mice exposed to $25 \mu \mathrm{g}$ of Der f1 (group E), and C57BL/6 mice exposed to $100 \mu \mathrm{g}$ of Der f1 (group F). PBS, phosphate buffered saline; HPF, high-power field. Bars represent standard error. Significantly different from control mice, ${ }^{*} P<0.05,{ }^{\star *} P<0.01$.

groups (Fig. 6). Groups B and E, which had been exposed to a low dose of Der f1, expressed higher levels of IL-25 than controls that had not been exposed to Der $\mathrm{f} 1$ and groups $\mathrm{C}$ and F, which had been exposed to a higher dose.

IL-33 is expressed in the nucleus of epithelial cells and released into the cytoplasm upon activation. In groups B, C, E, and $\mathrm{F}$, nuclear staining seemed to be stronger than in their respective control groups in both strains (groups A and C), but without statistical significance. In a quantitative analysis, there was no significant relationship between the expression of IL-33 and exposure to Der f1 dose or mouse strain (Fig. 7).

\section{BALB/c mice exposed to a low dose of Der $f 1$ showed higher expression of IL-4 and local chemokines in the nasal mucosa IL-4 mRNA expression was elevated in the nasal mucosa of groups B and C. Interestingly, IL-4 mRNA expression was signif-}

icantly higher in group $\mathrm{B}$, which received a low dose, than in group E $(P<0.001)$ (Fig. 8A). IL-5 mRNA expression was also significantly elevated in groups $\mathrm{B}$ and $\mathrm{C}(P=0.06)$ (Fig. $8 \mathrm{~B})$. Higher expression of IL-17 mRNA was also found in groups D and $\mathrm{E}$ (Fig. 8E). Interestingly, the highest expression of IFN- $\gamma$ mRNA was found in the C57BL/6 control group (Fig. 8F). In contrast, no significant differences were observed between the two strains for the expression of IL-6 and IL-10 mRNA (Fig. 8C and D).

Expression of eotaxin-1 and eotaxin-2 mRNA was also higher in $\mathrm{BALB} / \mathrm{c}$ mice (groups $\mathrm{B}$ and $\mathrm{C}$ ), than in the C57BL/6 groups that received the same treatment (group $\mathrm{B}, P<0.001$; group $\mathrm{C}$, $P<0.001)$ (Fig. 9A and B). There was a significant difference observed in expression of CXCL1 $(P<0.001)$ and CXCL2 $(P<$ $0.001)$ mRNA for the two mouse strains, particularly when they were challenged with a low dose of allergen (Fig. 9C and D). 

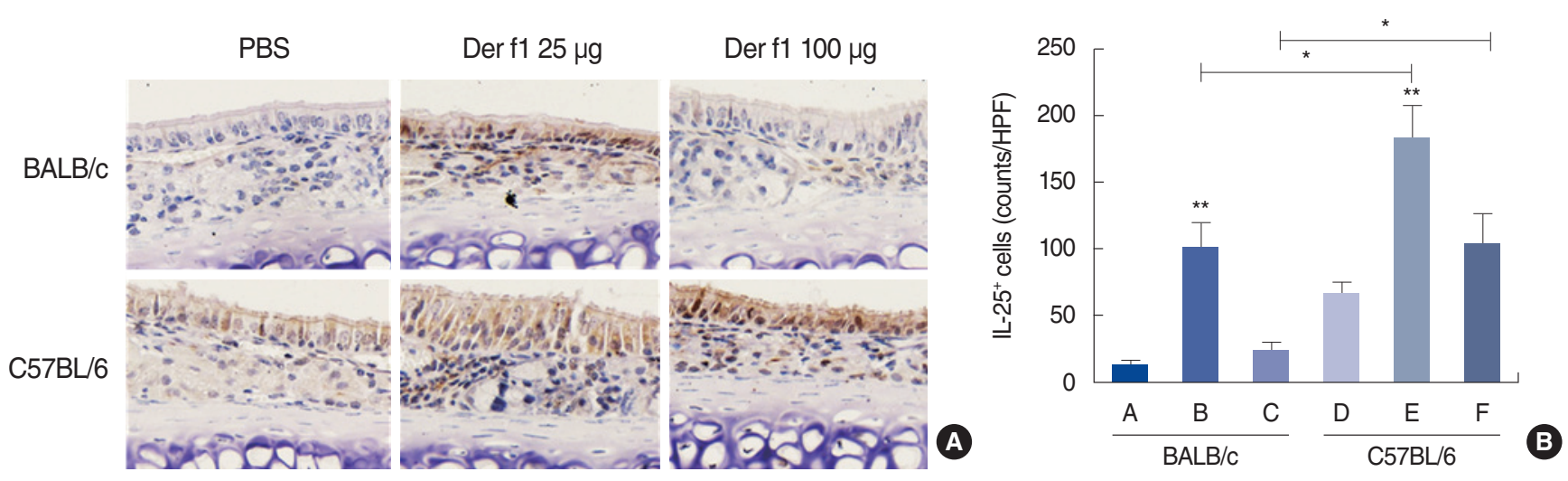

Fig. 6. Expression of interleukin (IL)-25 in the nasal mucosa. The panels show immunohistochemical findings for IL-25 ( $\times 400)$. Control group of BALB/c mice (group A), BALB/c mice exposed to $25 \mu \mathrm{g}$ of Dermatophagoides farinae (Der f1; group B), BALB/c mice group exposed to 100 $\mu \mathrm{g}$ of Der f1 (group C), control group of C57BL/6 mice (group D), C57BL/6 mice exposed to 25 mg of Der f1 (group E), and C57BL/6 mice exposed to $100 \mu \mathrm{g}$ of Der f1 (group F). PBS, phosphate buffered saline; HPF, high-power field. Bars represent standard error. Significantly different from control mice or significantly different between strains, ${ }^{\star} P<0.05,{ }^{\star *} P<0.01$.
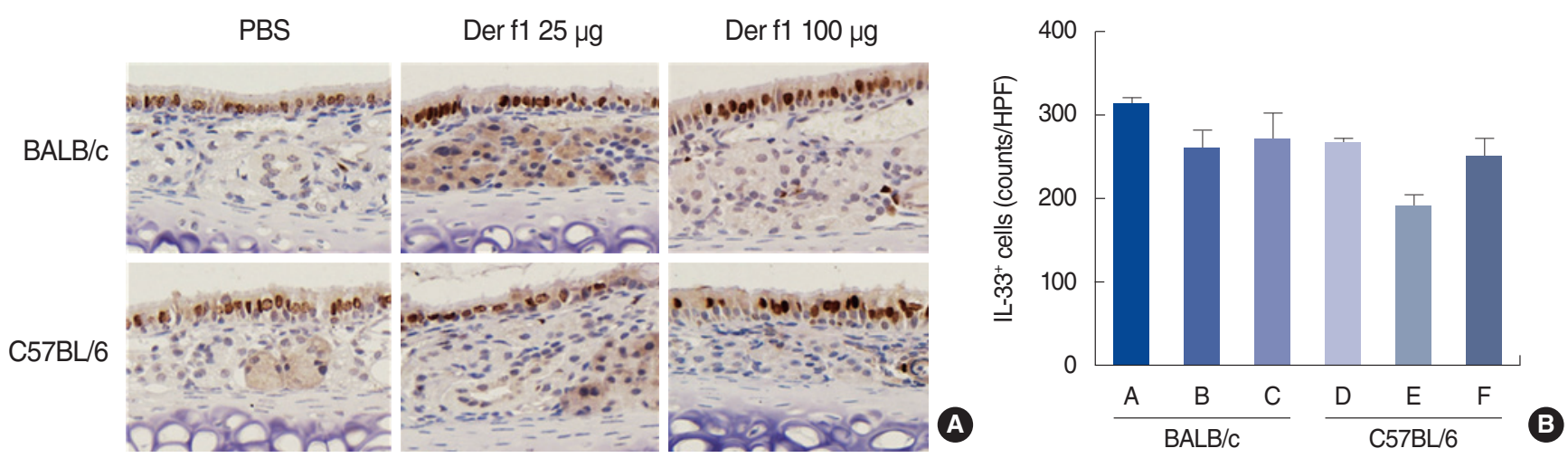

Fig. 7. Expression of interleukin (IL)-33 in the nasal mucosa. The panels show immunohistochemical findings for IL-33 ( $\times 400)$. Control group of BALB/c mice (group A), BALB/c mice exposed to $25 \mu \mathrm{g}$ of Dermatophagoides farinae (Der f1; group B), BALB/c mice group exposed to 100 $\mu \mathrm{g}$ of Der f1 (group C), control group of C57BL/6 mice (group D), C57BL/6 mice exposed to $25 \mu \mathrm{g}$ of Der f1 (group E), and C57BL/6 mice exposed to $100 \mu \mathrm{g}$ of Der f1 (group F). PBS, phosphate buffered saline; HPF, high-power field.

\section{BALB/c mice had stronger systemic Th2 cytokine responses than C57BL/6 mice}

IL-4 levels were measured using ELISA for groups A $(0.7 \pm 1.1$ $\mathrm{pg} / \mathrm{mL}), B(747.0 \pm 196.0 \mathrm{pg} / \mathrm{mL}), C(293.4 \pm 65.3 \mathrm{pg} / \mathrm{mL}), \mathrm{D}$ $(1.5 \pm 0.7 \mathrm{pg} / \mathrm{mL}), \mathrm{E}(13.3 \pm 13.4 \mathrm{pg} / \mathrm{mL})$, and $\mathrm{F}(11.5 \pm 7.3 \mathrm{pg} / \mathrm{mL})$. Groups B and C expressed higher levels of IL-4 than the other groups. Relative to the control, group B $(P<0.001)$ had the highest level of IL-4 (Fig. 10A). IL-4 expression was detected only at low levels in C57Bl/6 mice. Similarly, IL-5 levels were measured for groups A $(2.9 \pm 2.6 \mathrm{pg} / \mathrm{mL})$, B $(1,673.0 \pm 206.8 \mathrm{pg} / \mathrm{mL}), C$ $(1,055.5 \pm 114.2 \mathrm{pg} / \mathrm{mL}), D(3.6 \pm 2.7 \mathrm{pg} / \mathrm{mL}), \mathrm{E}(199.1 \pm 283.9$ $\mathrm{pg} / \mathrm{mL})$, and $\mathrm{F}(30.0 \pm 37.5 \mathrm{pg} / \mathrm{mL})$. Group B had a significantly higher IL-5 level $(P=0.002)$ than group E (Fig. 10B).

Levels of IL-6 were also measured in groups A $(4.6 \pm 4.6 \mathrm{pg} / \mathrm{mL})$, B $(339.3 \pm 75.0 \mathrm{pg} / \mathrm{mL})$, C $(223.1 \pm 91.0 \mathrm{pg} / \mathrm{mL}), \mathrm{D}(10.8 \pm 10.0$ $\mathrm{pg} / \mathrm{mL}), \mathrm{E}(156.2 \pm 228.9 \mathrm{pg} / \mathrm{mL})$, and $\mathrm{F}(71.5 \pm 31.7 \mathrm{pg} / \mathrm{mL})$. Group B, which received a low dose of Der f1, had the highest level of IL-6 expression, with a significant difference $(P<0.001)$ compared to the control group (Fig. 10C).

Levels of IL-10 protein were also measured in groups A $(10.4 \pm 12.4 \mathrm{pg} / \mathrm{mL}), B(2,650.0 \pm 280.5 \mathrm{pg} / \mathrm{mL}), C(1,847.5 \pm$ $297.6 \mathrm{pg} / \mathrm{mL}), \mathrm{D}(11.2 \pm 11.9 \mathrm{pg} / \mathrm{mL}), \mathrm{E}(43.6 \pm 56.4 \mathrm{pg} / \mathrm{mL})$, and $\mathrm{F}(8.9 \pm 15.4 \mathrm{pg} / \mathrm{mL})$. BALB/c mice that had been treated with low and high doses of Der f1 expressed higher levels of IL-10 ( $P<0.001$ for both) than the control group. However, no dose-dependent increase in IL-10 levels was found in a comparison of group B to group C (Fig. 10D). Similar to IL-4, only low levels of IL-10 were detected in C57BL/6 mice.

In contrast, when IL-17 levels were compared across groups A (1.8 $\pm 3.6 \mathrm{pg} / \mathrm{mL})$, B $(4.2 \pm 1.5 \mathrm{pg} / \mathrm{mL}), C$ ( $(10.1 \pm 8.9 \mathrm{pg} / \mathrm{mL}), D$ $(10.2 \pm 20.5 \mathrm{pg} / \mathrm{mL}), \mathrm{E}(15.3 \pm 26.5 \mathrm{pg} / \mathrm{mL})$, and F $(3.0 \pm 5.1 \mathrm{pg} / \mathrm{mL})$, we found that IL-17 expression was generally higher in C57BL/6 mice than in BALB/c mice. However, no statistical difference in IL-17 levels was detected between the two mouse strains (Fig. 

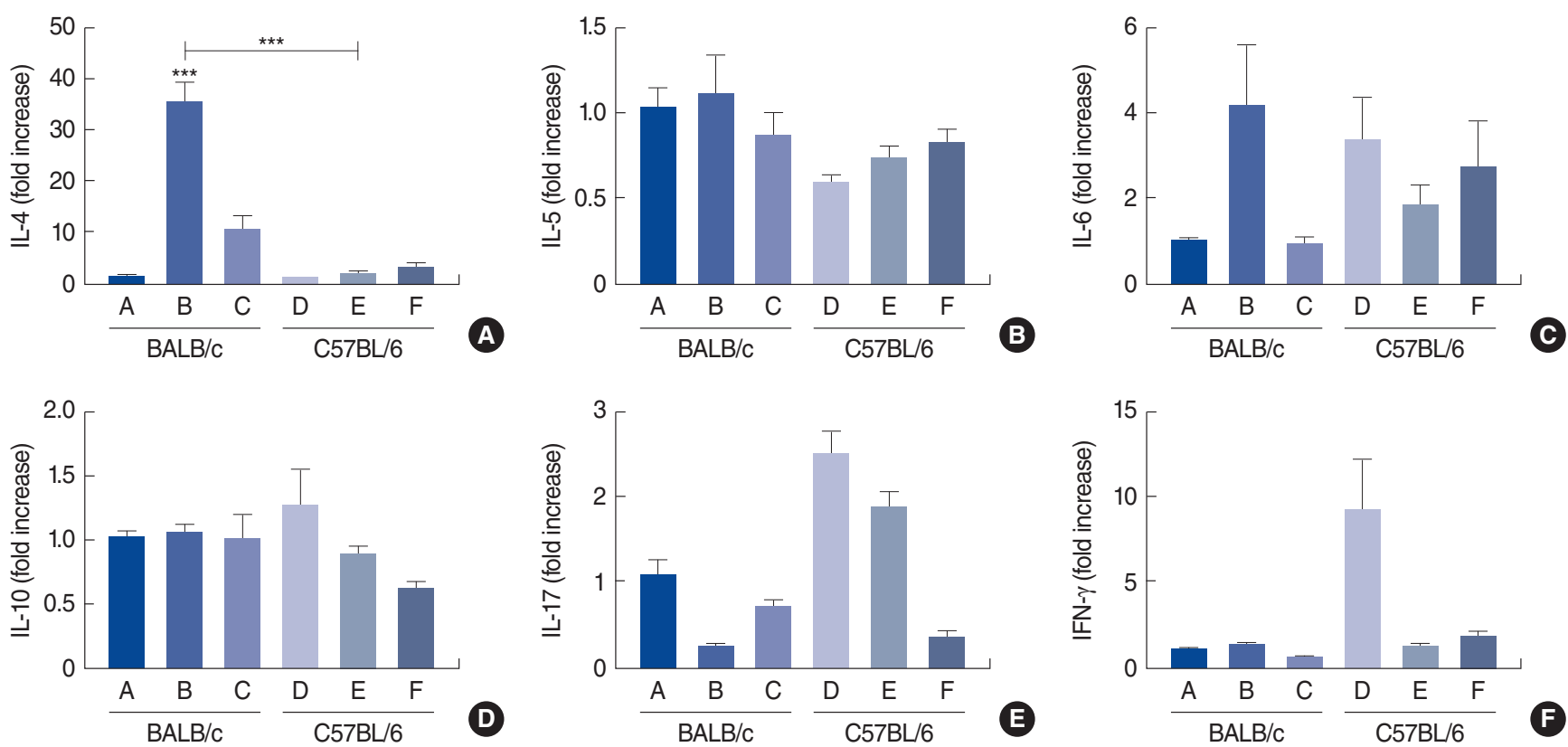

Fig. 8. Nasal mRNA expression of cytokines. Shown are interleukin (IL)-4 (A), IL-5 (B), IL-6 (C), IL-10 (D), IL-17 (E), and interferon (IFN)- $\gamma$ (F) levels in the control group of BALB/c mice (group A), BALB/c mice exposed to $25 \mu \mathrm{gg}$ of Dermatophagoides farinae (Der f1; group B), BALB/C mice group exposed to $100 \mu \mathrm{g}$ of Der f1 (group C), control group of C57BL/6 mice (group D), C57BL/6 mice exposed to $25 \mu \mathrm{g}$ of Der f1 (group E), and C57BL/6 mice exposed to $100 \mu \mathrm{g}$ of Der f1 (group F). Bars represent standard error. Significantly different from control mice or significantly different between strains, ${ }^{\star \star *} P<0.001$.
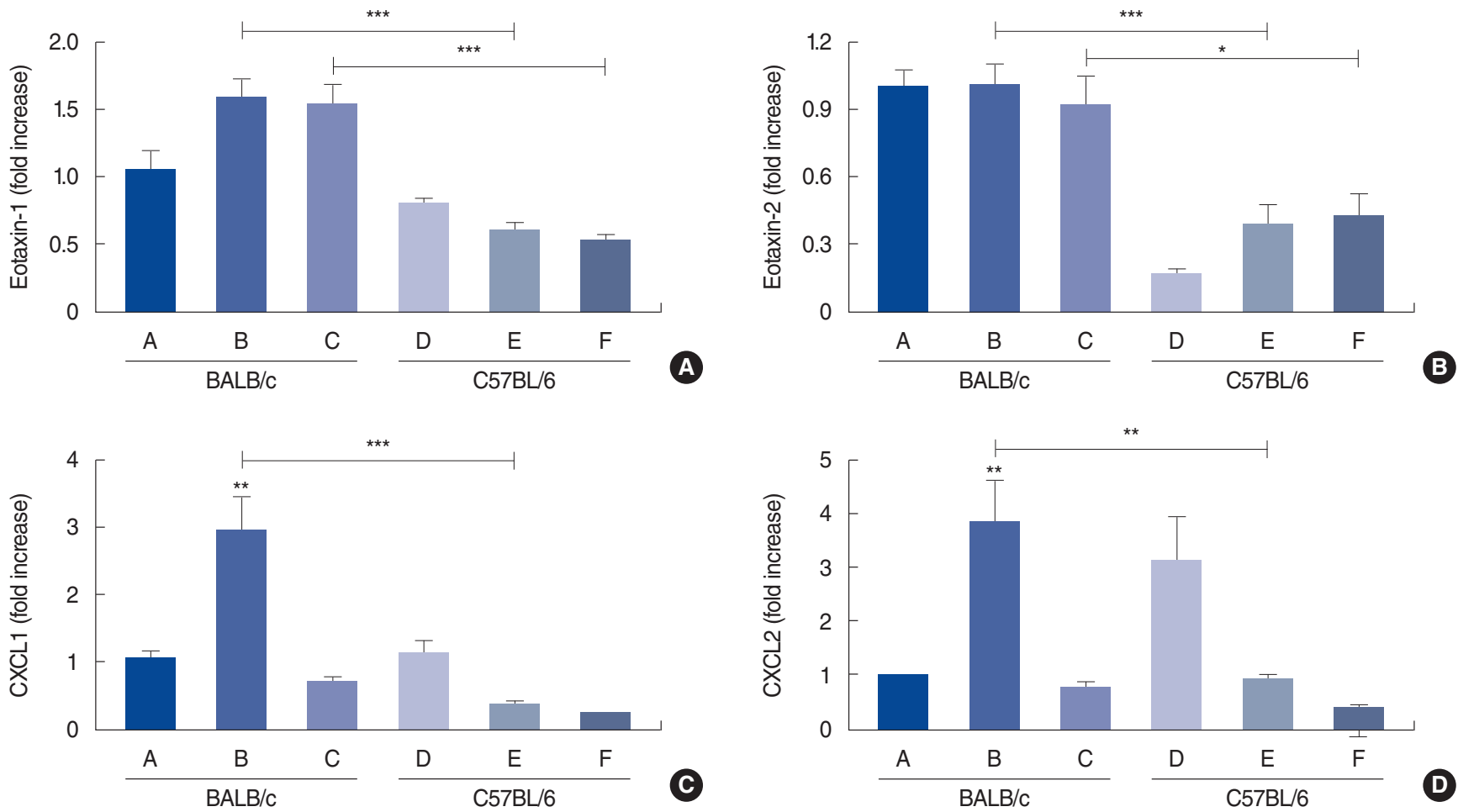

Fig. 9. Nasal mRNA expression of chemokines. Shown are eotaxin-1 (A), eotaxin-2 (B), CXCL1 (C), and CXCL2 (D) in the control group of BALB/c mice (group A), BALB/c mice exposed to $25 \mu \mathrm{g}$ of Dermatophagoides farinae (Der f1; group B), BALB/c mice group exposed to 100 $\mu \mathrm{g}$ of Der f1 (group C), control group of C57BL/6 mice (group D), C57BL/6 mice exposed to $25 \mu \mathrm{g}$ of Der f1 (group E), and C57BL/6 mice exposed to $100 \mu \mathrm{g}$ of Der f1 (group F). Bars represent standard error. Significantly different from control mice or significantly different between strains, ${ }^{\star} P<0.05,{ }^{* \star} P<0.01,{ }^{* \star} P<0.001$. 

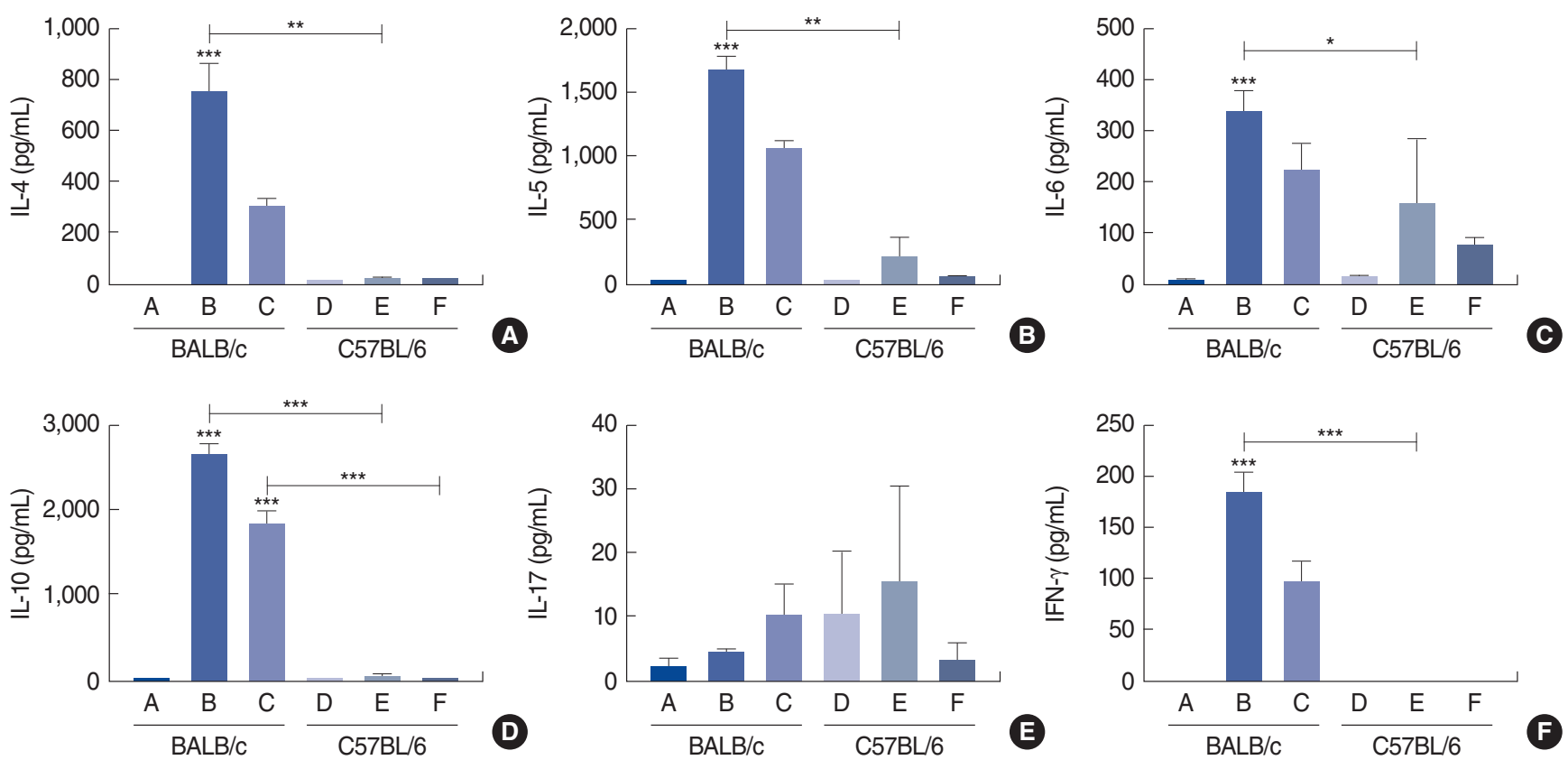

Fig. 10. Cytokine levels from splenocyte culture; interleukin (IL)-4 (A), IL-5 (B), IL-6 (C), IL-10 (D), IL-17 (E) and interferon (IFN)- $\gamma(F)$ in the control group of BALB/c mice (group A), BALB/c mice exposed to $25 \mu \mathrm{g}$ of Dermatophagoides farinae (Der f1; group B), BALB/c mice group exposed to $100 \mu \mathrm{g}$ of Der f1 (group C), control group of C57BL/6 mice (group D), C57BL/6 mice exposed to $25 \mu \mathrm{g}$ of Der f1 (group E), and C57BL/6 mice exposed to $100 \mu \mathrm{g}$ of Der f1 (group F). Bars represent standard error. Significantly different from control mice or significantly different between strains, ${ }^{*} P<0.05,{ }^{* \star} P<0.01,{ }^{* \star *} P<0.001$.

10E).

Finally, levels of IFN- $\gamma$ expression were also measured in groups A $(0.0 \pm 0.0 \mathrm{pg} / \mathrm{mL}), \mathrm{B}(183.4 \pm 36.0 \mathrm{pg} / \mathrm{mL}), \mathrm{C}(95.9 \pm 37.4 \mathrm{pg} / \mathrm{mL})$, $\mathrm{D}(0.0 \pm 0.0 \mathrm{pg} / \mathrm{mL}), \mathrm{E}(0.0 \pm 0.0 \mathrm{pg} / \mathrm{mL})$, and $\mathrm{F}(0.0 \pm 0.0 \mathrm{pg} / \mathrm{mL})$. Group B had the highest level of IFN- $\gamma$ expression, with a significant difference compared to the control group $(P<0.001)$ (Fig. 10F).

\section{DISCUSSION}

Animal models are used to study various pathologies, including allergies, rhinosinusitis, and infectious diseases [17-19]. Several animal studies have investigated the specific characteristics of lower airway inflammation in the context of allergies $[7,20]$. However, there is a knowledge gap on allergic inflammation in the upper airway. Thus, it is important to identify the optimal allergen doses required to elicit allergic responses in mouse models. There is a lack of data from previous studies regarding the optimal dosing for mouse models of allergic rhinitis, particularly with respect to differences between strains. Shibamori et al. [21] reported that C57BL/6 mice that were HDM-sensitized and challenged with Der f $(100 \mu \mathrm{g})$ exhibited increased airway hyper-responsiveness. Kelada et al. [9] also studied allergen-induced lower airway inflammation in two different mouse strains and demonstrated that C57BL/6 mice were clearly more responsive to higher doses of methacholine. We focused our atten- tion on allergic airway inflammation, particularly in the upper nasal airway. Our findings indicated that a challenge with a low dose of allergen $(25 \mu \mathrm{g})$ was best for yielding reproducible symptoms and inflammatory responses in both BALB/c and C57BL/6 mice. Accordingly, we suggest that a dose of $25 \mu \mathrm{g}$ of Der $\mathrm{f} 1$ is more appropriate for general sensitization in experimentally induced allergic rhinitis models.

Relatively high symptom scores were observed in the negative control groups for both BALB/c and C57BL/6 mice in this study. All mice were housed in the same environment and all experiments were performed under the same conditions. The relatively high symptom scores in the negative control groups could have been due to mechanical irritation caused by PBS, and it is not unusual to observe symptom scores in that range in negative control groups. Notably, we observed a significant elevation in symptom scores in mice that received a low-dose challenge with Der f1. Interestingly, symptom scores and immunoglobulin levels did not increase further with higher doses of Der f1. The present study is one of the first to compare the immunological responses induced by different allergen dosages in different mouse strains, and we identified a diminished response at higher dosages. Previous reports have described a suppressed immune response after administration of high doses of antigen [22,23]. Although higher doses of drugs are expected to induce a stronger response in a dose-dependent manner, it seems that this is not applicable to antigens. Administration of suboptimal or high doses of antigen can paradoxically suppress immune responses to the antigen [22]. 
In general, when a given antigen is administered over a wide range of concentrations, intermediate doses induce immunity, whereas low and high doses induce tolerance. Immune tolerance could be an explanation for the lower responses observed in response to a higher dose of Der f1.

Total serum IgE levels have been previously analyzed in various mouse strains $[7,9,21]$. Those studies showed that BALB/c mice exhibited lower total serum IgE levels than other mouse strains, in particular other Th2-biased strains such as BP2 and A/J. Generally, levels of Th2 cytokines such as IL-4 are associated with increases in total serum IgE levels. In the current study, we showed a robust increase in total serum IgE levels in the Th2-biased BALB/c mouse strain when challenged with a low dose of Der f1, suggesting that BALB/c mice are more appropriate for a model of Der f1-induced allergic rhinitis than C57BL/6 mice.

Eosinophil infiltration into upper airway tissue is a primary characteristic of allergic inflammation. Tissue eosinophilia during allergic responses is mainly characteristic of Th2 immune responses, such as those elicited by IL-5 and CCL11/eotaxins. Th2-biased mouse strains such as BALB/c, BP2, and A/J have been reported to reproduce the characteristics of human allergic responses better than the Th1-biased mouse strains C57BL/6, DBA/2, CBA, and AKR [7]. Specifically, those researchers found that BALB/c mice consistently showed robust eosinophil and neutrophil infiltration. Accordingly, they suggested that BALB/c mice are a better model for airway inflammation and associated immunological changes than other Th2-biased mouse strains and Th1-biased mice [7,24-26]. In this study, BALB/c and C57BL/6 mice showed similar levels of eosinophil and neutrophil infiltration in the nasal mucosa.

The mechanisms underlying the immune reactions elicited by allergic airway inflammation remain poorly understood. Our findings also showed a discrepancy between eosinophil infiltration and mRNA expression of associated chemotactic factors. While the mRNA levels of eotaxin- 1 and eotaxin- 2 were higher in BALB/c mice than in C57BL/6 mice, no upregulation was observed in groups challenged with Der f1. This suggests that rather than control on the transcriptional level, eotaxin-1 and eotaxin- 2 are post-transcriptionally and/or post-translationally regulated.

It has also been reported that levels of Th2 cytokines, including IL-4, may not always be correlated with total serum IgE levels [7]. The authors of that study suggested that while IL-4 plays an important role in the production of IgE [27], it also mediates other pathways, such as those associated with the differentiation of Th-lymphocytes [7]. Our data showed that the IL-4 levels in the Th2-biased BALB/c strain increased significantly when challenged with a low dose of allergen. In contrast, levels of IL-17 in the nasal mucosa were elevated in Th1-biased (C57BL/6) mice, and no strain-dependent differences were observed for other local cytokines such as IL-5, IL-6, IL-10, and IFN- $\gamma$. Most systemic cytokines (including IL-4, IL-5, IL-6, and IL-10) were consistently expressed at higher levels in Th2-biased BALB/c mice. Interestingly, the expression of IFN- $\gamma$ showed an opposite trend to what we expected.

The key finding of this study is that overall, Th2-biased BALB/c mice better reproduced allergic responses thanTh1-biased C57BL/6 mice; thus, these mice are a better model of allergic rhinitis. However, we also found that airway tissue inflammation is not necessarily correlated with local and systemic Th2 cytokine expression.

There is no doubt that immunological reactions to allergens are complex and have many different components that involve numerous regulatory mechanisms. This is particularly true in experimental models of allergic rhinitis. One limitation of this study is the lack of mechanistic details underlying strain differences, as only phenotypic differences were described. To elucidate the reasons for strain-specific differences in the immune response, more experiments are necessary. Additional studies are also required in the long term for the development of clinical applications.

\section{CONFLICT OF INTEREST}

No potential conflict of interest relevant to this article was reported.

\section{ACKNOWLEDGMENTS}

This research was supported by the Basic Science Research Program through the National Research Foundation of Korea (NRF) funded by the Ministry of Science, ICT and Future Planning (NRF-2016R1A2B4010407).

This work was supported by the Research Resettlement Fund for new faculty of Konyang University Hospital.

\section{ORCID}

$\begin{array}{ll}\text { Ki-Il Lee } & \text { https://orcid.org/0000-0002-2069-7912 } \\ \text { Jun-Sang Bae } & \text { https://orcid.org/0000-0003-2589-797X } \\ \text { Eun Hee Kim } & \text { https://orcid.org/0000-0002-9539-9928 } \\ \text { Ji Hye Kim } & \text { https://orcid.org/0000-0003-2516-774X } \\ \text { Lele Lyu } & \text { https://orcid.org/0000-0003-1600-0817 } \\ \text { Young-Jun Chung } & \text { https://orcid.org/0000-0002-3789-3485 } \\ \text { Ji-Hun Mo } & \text { https://orcid.org/0000-0003-1331-364X }\end{array}$

\section{AUTHOR CONTRIBUTIONS}

Conceptualization: JHM. Data curation: KIL, JSB, EHK, JHK. Formal analysis: KIL, JSB, EHK. Funding acquisition: JHM. Methodology: JSB, EHK, JHK, LL. Project administration: JSB, 
EHK, JHK, YJC, JHM. Visualization: EHK, JHK. Writing-original draft: KIL.Writing-review \& editing: KIL, JHM.

\section{REFERENCES}

1. Passali D, Cingi C, Staffa P, Passali F, Muluk NB, Bellussi ML. The international study of the allergic rhinitis survey: outcomes from 4 geographical regions. Asia Pac Allergy. 2018 Jan;8(1):e7.

2. Wise SK, Lin SY, Toskala E, Orlandi RR, Akdis CA, Alt JA, et al. International Consensus Statement on Allergy and Rhinology: allergic rhinitis. Int Forum Allergy Rhinol. 2018 Feb;8(2):108-352.

3. Kim BY, Park HR, Shin JH, Kim SW, Kim SW. Human placental extract reduces allergic inflammation in a murine allergic rhinitis model. Laryngoscope. 2014 Oct;124(10):E399-404.

4. Han DH, Shin JM, An S, Kim JS, Kim DY, Moon S, et al. Long-term breastfeeding in the prevention of allergic rhinitis: Allergic Rhinitis Cohort Study for Kids (ARCO-Kids Study). Clin Exp Otorhinolaryngol. 2019 Aug;12(3):301-7.

5. Lee DJ, Chung YJ, Yang YJ, Mo JH. The impact of allergic rhinitis on symptom improvement in pediatric patients after adenotonsillectomy. Clin Exp Otorhinolaryngol. 2018 Mar;11(1):52-7.

6. Scadding G. Cytokine profiles in allergic rhinitis. Curr Allergy Asthma Rep. 2014 May;14(5):435.

7. De Vooght V, Vanoirbeek JA, Luyts K, Haenen S, Nemery B, Hoet $\mathrm{PH}$. Choice of mouse strain influences the outcome in a mouse model of chemical-induced asthma. PLoS One. 2010 Sep;5(9):e12581.

8. Okano M, Nishizaki K, Abe M, Wang MM, Yoshino T, Satoskar AR, et al. Strain-dependent induction of allergic rhinitis without adjuvant in mice. Allergy. 1999 Jun;54(6):593-601.

9. Kelada SN,Wilson MS, Tavarez U, Kubalanza K, Borate B, Whitehead GS, et al. Strain-dependent genomic factors affect allergen-induced airway hyperresponsiveness in mice. Am J Respir Cell Mol Biol. 2011 Oct;45(4):817-24.

10. Mo JH, Lee SE, Wee JH, Lee JE, Rhee CS, Lee CH, et al. Anti-allergic effects of So-Cheong-Ryong-Tang, a traditional Korean herbal medicine, in an allergic rhinitis mouse model. Eur Arch Otorhinolaryngol. 2013 Mar;270(3):923-30.

11. Zhang YL, Shin HJ, Lee JH, Lee J. Antiallergic effect of Hizikia fusiformis in an ovalbumin-induced allergic rhinitis mouse model. Clin Exp Otorhinolaryngol. 2019 May;12(2):196-205.

12. Cho JS, Kang JH, Han IH, Um JY, Park IH, Lee SH, et al. Antiallergic effects of Trichostatin $A$ in a murine model of allergic rhinitis. Clin Exp Otorhinolaryngol. 2015 Sep;8(3):243-9.

13. Lee JE, Zhang YL, Han DH, Kim DY, Rhee CS. Antiallergic function of KR62980, a peroxisome proliferator-activated receptor- $\gamma$ agonist, in a mouse allergic rhinitis model.Allergy Asthma Immunol Res. 2015
May;7(3):256-64

14. Kim DH, ParkYS, Jang HJ, Kim JH, Lim DH. Prevalence and allergen of allergic rhinitis in Korean children. Am J Rhinol Allergy. 2016 May; 30(3):72-8.

15. Shin YS, Jung CG, Park HS. Prevalence and clinical characteristics of local allergic rhinitis to house dust mites. Curr Opin Allergy Clin Immunol. 2018 Feb;18(1):10-5.

16. Yasue M, Yokota T, Suko M, Okudaira H, Okumura Y. Comparison of sensitization to crude and purified house dust mite allergens in inbred mice. Lab Anim Sci. 1998 Aug;48(4):346-52.

17. Raberg L, Sim D, Read AF. Disentangling genetic variation for resistance and tolerance to infectious diseases in animals. Science. 2007 Nov;318(5851):812-4.

18. Sahu N, Morales JL, Fowell D, August A. Modeling susceptibility versus resistance in allergic airway disease reveals regulation by Tec kinase Itk. PLoS One. 2010 Jun;5(6):e11348.

19. Lee KI, Kim DW, Kim EH, Kim JH, Samivel R, Kwon JE, et al. Cigarette smoke promotes eosinophilic inflammation, airway remodeling, and nasal polyps in a murine polyp model.Am J Rhinol Allergy. 2014 May-Jun;28(3):208-14.

20. Sakai K, Yokoyama A, Kohno N, Hiwada K. Effect of different sensitizing doses of antigen in a murine model of atopic asthma. Clin Exp Immunol. 1999 Oct;118(1):9-15.

21. Shibamori M, Ogino K, Kambayashi Y, Ishiyama H. Intranasal mite allergen induces allergic asthma-like responses in NC/Nga mice. Life Sci. 2006 Jan;78(9):987-94.

22. Suzuki G, Kawase Y, Koyasu S, Yahara I, Kobayashi Y, Schwartz RH. Antigen-induced suppression of the proliferative response of $\mathrm{T}$ cell clones. J Immunol. 1988 Mar;140(5):1359-65.

23. Byers VS, Sercarz EE. Induction and reversal of immune paralysis in vitro. J Exp Med. 1970 Nov;132(5):845-57.

24. Vanoirbeek JA, Tarkowski M, Vanhooren HM, De Vooght V, Nemery B, Hoet PH.Validation of a mouse model of chemical-induced asthma using trimellitic anhydride, a respiratory sensitizer, and dinitrochlorobenzene, a dermal sensitizer. J Allergy Clin Immunol. 2006 May;117(5):1090-7.

25. Vanoirbeek JA,Tarkowski M, Ceuppens JL,Verbeken EK, Nemery B, Hoet $\mathrm{PH}$. Respiratory response to toluene diisocyanate depends on prior frequency and concentration of dermal sensitization in mice. Toxicol Sci. 2004 Aug;80(2):310-21.

26. Vanoirbeek JA, DeVooght V, Nemery B, Hoet PH. Multiple challenges in a mouse model of chemical-induced asthma lead to tolerance: ventilatory and inflammatory responses are blunted, immunologic humoral responses are not.Toxicology. 2009 Mar;257(3):144-52.

27. Zhang Y, Lamm WJ, Albert RK, Chi EY, Henderson WR Jr, Lewis DB. Influence of the route of allergen administration and genetic background on the murine allergic pulmonary response. Am J Respir Crit Care Med. 1997 Feb;155(2):661-9. 